\title{
Osteoblast differentiation from synovial fluid cells in juvenile idiopathic arthritis (JIA)
}

\author{
Marija Jelusic-Drazic ${ }^{*}$, Elvira Lazic Mosler ${ }^{2}$, Danka Grcevic ${ }^{2}$, Mandica Vidovic ${ }^{1}$, Ana Marusic ${ }^{2}$, Natasa Kovacic ${ }^{2}$ \\ From 2011 Pediatric Rheumatology Symposium sponsored by the American College of Rheumatology \\ Miami, FL, USA. 2-5 June 2011
}

\begin{abstract}
Purpose
Juvenile idiopathic arthritis (JIA) is one of the leading causes of disability in children characterized by destruction of articular cartilage and underlying bone, as well as synovial hyperplasia. Since synovia contains osteoblast progenitors, hyperplastic changes may contribute to joint destruction by inhibition of osteoblast differentiation. Osteoblasts are also immunoregulatory cells and their inhibited differentiation and function may affect joint inflammation. The objective of this report is to explore the osteoblastogenic potential of synovial fluid cells in JIA and to examine whether synovial fluid from children with JIA effects osteoblast differentiation of human bone marrow cells in vitro. Additionaly, we aimed to determine and compare the local and systemic expression of osteoblast related genes in patients with JIA.
\end{abstract}

\section{Methods}

Blood samples were obtained from 21 children with oligoarticular JIA (OJIA), 21 children with polyarticular JIA (pJIA), and 24 control children. Synovial fluid samples were collected from 21 children with oJIA and 6 children with pJIA. Peripheral blood cells from healthy controls and children with JIA, as well as synovial fluid cells from children with JIA were used to analyze the gene expression of Runx1, Runx2, Runx3, osteoprotegerin (OPG) and receptor activator of nuclear factor kappa-B ligand (RANKL) by quantitative polymerase chain reaction. Osteoblastogenesis from synovial cells was induced in $\alpha$ MEM medium supplemented with $10 \%$ fetal bovine serum, $50 \mu \mathrm{g} / \mathrm{ml}$ ascorbic acid and $5 \mathrm{mmol} \beta$-glycerophosphate, and assessed by alkaline phospatase (AP) staining of osteoblast colonies on culture day 21 . The human bone marrow cells from healthly donor were cultured for
17 days with $10 \%$ synovial fluid from children with JIA. Osteoblast differentiation was compared with non-treated cells, assessed by AP activity.

\section{Results}

Synovial cells from children with oJIA formed more AP positive colonies on culture day 21 , in comparison to synovial cells from children with pJIA $(784.81 \pm 216.79$ vs. $257.21 \pm 68.13$ arbitrary units, $\mathrm{p}<0.001$, t-test). As assessed by AP activity synovial fluid from children both with oJIA and pJIA inhibited osteoblast differentiation of human bone marrow cells $(0.059 \pm 0.026$ in oJIA; 0.068 \pm 0.019 in pJIA vs. $0,115 \pm 0,023$ in control cultures, $\mathrm{p}<0.05$, t-test). Gene expression of Runx1, Runx2, Runx3 and RANKL was higher in synovial fluid of children with pIIA than with oJIA.The expression of osteoblast related genes in peripheral blood mononuclear cells from children with JIA was similar to healthy controls.

\section{Conclusion}

Osteoblast differentiation is locally inhibited in children with JIA, which is particularly pronounced in poliarticular disease. Osteoblast differentiation potential of synovial cells may serve as an important prognostic and therapeutic factor in JIA

\section{Disclosure}

Marija Jelusic-Drazic: None; Elvira Lazic Mosler: None; Danka Grcevic: None; Mandica Vidovic: None; Ana Marusic: None; Natasa Kovacic: None.

\section{Author details \\ ${ }^{1}$ University Hospital Center Zagreb, Zagreb, Croatia, Croatia. ${ }^{2}$ University of Zagreb School of Medicine, Zagreb, Croatia.}

Published: 13 July 2012

${ }^{1}$ University Hospital Center Zagreb, Zagreb, Croatia, Croatia

Full list of author information is available at the end of the article 
doi:10.1186/1546-0096-10-S1-A115

Cite this article as: Jelusic-Drazic et al: Osteoblast differentiation from synovial fluid cells in juvenile idiopathic arthritis (JIA). Pediatric

Rheumatology 2012 10(Suppl 1):A115.

Submit your next manuscript to BioMed Central and take full advantage of:

- Convenient online submission

- Thorough peer review

- No space constraints or color figure charges

- Immediate publication on acceptance

- Inclusion in PubMed, CAS, Scopus and Google Scholar

- Research which is freely available for redistribution

Submit your manuscript at www.biomedcentral.com/submit 